\title{
PENGAWASAN DAN KOORDINASI KERJA SERTA PENGARUHNYA TERHADAP PRODUKTIVITAS KERJA KARYAWAN
}

\author{
Arif Rahman Putra \\ Dosen Fakultas Ekonomi Universitas Mayjen Sungkono Mojokerto \\ e-mail: Arsy.caniago@gmail.com \\ Didit Darmawan \\ Dosen Fakultas Ekonomi Universitas Mayjen Sungkono Mojokerto \\ e-mail:dr.diditdarmawan@gmail.com \\ Ella Anastasya Sinambela \\ Dosen Fakultas Ekonomi Universitas Mayjen Sungkono Mojokerto \\ e-mail:ella_sinambela@gmail.com
}

\begin{abstract}
Human resources are an asset for the organization to achieve its goals and this means that the organization needs qualified human resources to run its perasional. To achieve this, organizations need to monitor and coordinate work. The result of supervision and work coordination is expected to give effect to work productivity. The purpose of this research is (1) to know and analyze the partial influence of supervision and work coordination on work productivity; (2) to know and analyze the effect simultaneously supervision and coordination of work on employee work productivity; and (3) to know and analyze which is more dominant among supervision and work coordination to work productivity of employees. The research was conducted in one of the largest factories in sidoarjo city with 10000 employees. Samples were taken as many as 200 people with random technique. The data is done by using SPSS program with multiple regression analysis method. The results of the research are (1) supervision and coordination of work have a significant effect partially on work productivity; (2) supervision and coordination of work have significant effect simultaneously on work productivity; (3) work supervision proved to have a significant dominant influence on work productivity.
\end{abstract}

Keywords : supervision, coordination, work productivity

\section{PENDAHULUAN}

Sumber daya manusia (SDM) merupakan aset bagi organisasi untuk mencapai tujuan dan kesuksesan. Hal ini berarti organisasi memerlukan sumber daya manusia yang berkualitas untuk menjalankan operasionalnya. Dengan demikian organisasi memerlukan tata kelola yang tepat untuk memberdayakan sumber daya manusia yang tersedia. Adanya peningkatan kualitas sumber daya manusia sangat diperlukan sehingga para anggota dapat menjalankan tugas dan akhirnya dapat memperlancar serta mempercepat tercapainya tujuan organisasi. Oleh sebab itu anggota harus memiliki karakteristik antara lain: keterampilan dan keakhlian yang tinggi, wawasan dan pengetahuan yang luas, bakat dan potensi, kepribadian dan 
motif kerja serta moral dan etos kerja yang tinggi. Karakteristik individu setiap anggota organisasi didukung pula oleh karakteristik kerja yang khas yang terbentuk dari suatu sistem kerja. Sistem kerja memerlukan pengawasan dan koordinasi kerja untuk mendukung produktivitas kerja para karyawan.

Pengawasan kerja yang efektif akan menumbuh kembangkan rasa tanggung jawab yang besar dalam diri kayawan sehingga mampu mengendalikan perilaku dan hasil kerjanya. Pengawasan kerja yang baik dan kohesif akan mempengaruhi karyawana untuk bekerja lebih produktif dengan kehatian-hatian mengolah bahan baku yang dipercayakan kepadanya (Darmawan, 2013). Pengawasan kerja mempunyai dampak dan pengaruh yang cukup besar terhadap produktivitas kerja karyawan.

Upaya pengelolaan organisasi yang sesuai dengan kebutuhan pelaksanaan misi dan tujuan organisasi sangat tergantung pada strategi pengelolaan sumber daya manusia dan komunikasi kerja selama proses operasional berlangsung. Oleh karena itu diperlukan koordinasi kerja. Koordinasi kerja membantu karyawan memahami intruksi pimpinan untuk bekerja secara tim dalam lingkungan organisasi. Hakikat dari koordinasi kerja diarahkan pada perencanaan yang efektif dan sistematis menjalankan tanggung jawab masing-masing dari karyawan (Gunawan, 2017).

Berdasarkan pada uraian latar belakang permasalahan tersebut, maka penulis mencoba mengambil topik penelitian dengan judul penelitian sebagai berikut pengaruh pengawasan dan koordinasi kerja terhadap produktivitas kerja karyawan. Tujuan dari penelitian ini adalah (1) untuk mengetahui dan menganalisa pengaruh parsial pengawasan dan koordinasi kerja terhadap produktivitas kerja; (2) untuk mengetahui dan menganalisa pengaruh secara simultan pengawasan dan koordinasi kerja terhadap produktivitas kerja karyawan; dan (3) untuk mengetahui dan menganalisa manakah yang lebih dominan diantara pengawasan dan koordinasi kerja terhadap produktivitas kerja karyawan.

\section{Pengawasan Kerja}

Pengawasan mempunyai arti penting bagi setiap perusahaan. Pengawasan bertujuan agar hasil pelaksanaan pekerjaan diperoleh secara berdaya guna (efisien) dan berhasil guna (efektif), sesuai dengan rencana yang telah ditetapkan sebelumnya. Meski demikian pengawasan hanyalah sebagai alat, oleh karena itu pelaksanaan pengawasan haruslah untuk mempermudah tercapainya tujuan. Menurut Siagian (2008) pengawasan adalah proses pengamatan dari pada pelaksanaan seluruh kegiatan organisasi untuk menjamin agarsupaya semua pekerjaan yang dilaksanakan sesuai dengan rencana yang telah ditentukan sebelumnya. Menurut Handoko (2013), pengawasan adalah suatu usaha sistematik untuk menetapkan standart pelaksanaan dengan tujuan-tujuan perencanaan, merancang sistem informasi umpan balik, membandingkan kegiatan nyata dengan standar yang telah ditetapkan sebelumnya, menentukan dan mengukur penyimpangan-penyimpangan serta mengambil tindakan koreksi yang diperlukan untuk menjamin bahwa semua sumber daya perusahaan dipergunakan dengan cara paling efektif dan efisien dalam pencapaian tujuan-tujuan perusahaan.

Menurut Kadarisman (2013) pengawasan sumber daya manusia merupakan kegiatan yang dilakukan untuk mengendalikan pelaksanaan tugas atau pekerjaan 
yang dilakukan seseorang, agar proses pekerjaan tersebut sesuai dengan hasil yang diinginkan. Pengawasan adalah fungsi manajemen fungsional yang harus dilaksanakan oleh setiap pimpinan terhadap pelaksanaan pekerjaan atau karyawan yang melaksanakan sesuai dengan tugas pokoknya masing-masing. Dengan demikian, pengawasan oleh pimpinan, khususnya yang berupa pengawasan melekat (built in control), merupakan kegiatan manajerial yang dilakukan dengan tujuan tidak terjadi penyimpangan dalam melaksanakan pekerjaan. Suatu penyimpangan atau kesalahan terjadi atau tidak selama dalam pelaksanaan pekerjaan tergantung pada tingkat kemampuan dan keterampilan para karyawan.

\section{Koordinasi Kerja}

Koordinasi adalah suatu usaha yang sinkron untuk menyediakan jumlah dan waktu yang tepat dan mengarahkan pelaksanaan untuk menghasilkan suatu tindakan yang seragam dan harmonis pada sasaran yang telah ditentukan (Handayaningrat, 2002). Handoko (2013) mendefinisikan koordinasi sebagai proses pengintegrasian tujuan-tujuan dan kegiatan-kegiatan pada satuansatuan yang terpisah (departemen atau bidang-bidang fungsional) suatu organisasi untuk mencapai tujuan organisasi secara efisien. Menurut Siagian (2008) koordinasi merupakan kegiatan yang menyatukan berbagai kegiatan yang saling berbedabeda akan tetapi mempunyai tujuan yang saling berhubungan. Syafrudin (2003) bahwa koordinasi memegang peranan penting untuk meningkatkan efektivitas kerja yaitu melalui kesempatan yang diberikan oleh pemimpin kepada karyawan untuk mengembangkan dan meningkatkan kemampuan serta keterampilannya merupakan unsur yang membentuk produktivitas karyawan yang pada akhirnya dapat menunjukan efektivitas kerja di organisasi. Sasaran utama koordinasi adalah untuk menciptakan "unity action" yang pada gilirannya akan menjamin keterpaduan pelaksanaan dan sekaligus meningkatkan efesiensi, efektivitas dan produktivitas kerjasama komponen yang terlibat.

Hasibuan (2013) menyatakan bahwa ada dua tipe koordinasi dalam suatu perusahaan, yaitu : koordinasi vertikal dan koordinasi horizontal. Koordinasi vertikal adalah kegiatan-kegiatan penyatuan, pengarahan yang dilakukan oleh atasan terhadap kegiatan unit-unit, kesatuan-kesatuan kerja yang ada dibawah wewenang dan tanggung jawabnya. Koordinasi horizontal adalah mengkoordinasikan tindakan-tindakan atau kegiatan-kegiatan penyatuan, pengarahan yang dilakukan terhadap kegiatan-kegiatan dalam tingkat organisasi yang setingkat.

\section{Produktivitas Kerja}

Produktivitas tenaga kerja sebenarnya hanya sebagian dari seluruh produktivitas suatu usaha. Namun demikian produktivitas adalah yang paling menentukan sekaligus yang paling untuk sulit dimengerti. Menurut Siagian (2008), produktivitas kerja merupakan kemampuan memperoleh manfaat dari sarana dan prasarana yang tersedia dengan menghasilkan kerja yang optimal bahkan kalau mungkin maksimal. Kemampuan yang dimaksud dalam defenisi tersebut tidak hanya berhubungan dengan sarana dan prasarana, tetapi juga berhubungan dengan pemanfaatan waktu dan sumber daya manusia. Sehubungan 
dengan itu produktivitas kerja dikatakan tinggi jika prosesnya berlangsung menurut prosedur dan mekanisme yang tepat dan cermat atau yang dinilai terbaik dalam melaksanakan suatu pekerjaan. Hasil kerja personel secara kuantitatif tidak segera dapat diamati, namun ketepatan dan kecermatan mempergunakan metode atau alat sebagai indikator yang dapat menjamin kualitas hasil yang akan tercapai selalu dapat diamati. Dalam keadaan seperti itu berarti daya guna (efisiensi) kerja, dapat juga berarti produktivitas kerja. Dengan kata lain pekerjaan yang dilaksanakan secara berdaya guna, merupakan juga pekerjaan yang produktif. Produktivitas erat terkait dengan hasil kerja yang dicapai oleh karyawan.

Menurut Gunawan (2017) produktivitas kerja merupakan suatu ukuran terakhir keberhasilan perusahaan dalam mengelola sumber daya manusia. Penilaian produktivitas kerja pada dasarnya merupakan salah satu faktor kunci guna mengembangkan suatu organisasi secara efektif dan efisien. Pengukuran produktivitas kerja dilihat dari hasil prestasi yang diraih oleh karyawan dengan melihat faktor-faktor yang meliputinya, antara lain kualitas kerja, kuantitas output, kehandalan dan sikap. Perlakuan yang dibuat sedemikian rupa oleh perusahaan dalam memaksimalkan tingkat produktivitas tidak terlepas dari kerja dan manusianya. Kedua hal itu tentu saja saling berkaitan erat karena manusialah yang mengadakan perubahan-perubahan dan membuat gerak mesin-mesin dalam proses pembuatan suatu produk (Darmawan, 2013). Menurut Bacal (2002), produktivitas bukanlah membuat karyawan bekerja lebih lama atau lebih keras. Peningkatan produktivitas lebih banyak merupakan hasil dari perencanaan yang tepat, dari investasi yang bijaksana, dari teknologi, dari teknik yang lebih baik dan dari efisiensi yang lebih tinggi; dengan kata lain dari pelaksanaan manajemen yang baik. Menurut Armstrong (2010), di luar ini produktivitas sangat tergantung pada usaha yang penuh kesadaran dari tiap-tiap karyawan atau kesediaan untuk bekerja secara baik untuk memperoleh gaji yang memadai.

\section{Kerangka Konseptual Penelitian}

Penelitian ini akan mencari pengaruh pengawasan dan koordinasi kerja secara parsial dan secara simultan terhadap produktivitas kerja karyawan. Ketiga variabel tersebut akan dianalisis untuk mengetahui hubungan antar variabel tersebut. Untuk tujuan tersebut, maka kerangka konseptual penelitian ditunjukkan pada Gambar 1 berikut ini.

Gambar 1

Kerangka Konseptual Penelitian

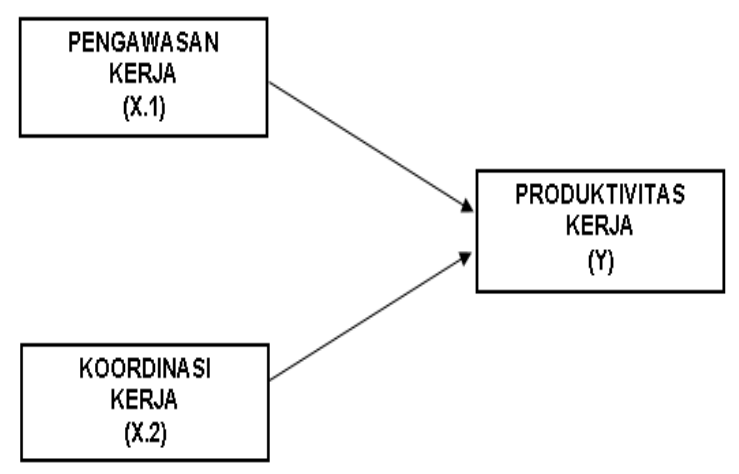




\section{Hipotesis Penelitian}

Berdasarkan landasan teoritis dan hasil penelitian terdahulu yang telah diuraikan sebelumnya, maka hipotesis di penelitian ini adalah (1) pengawasan dan koordinasi kerja memiliki pengaruh signifikan secara parsial terhadap produktivitas kerja; (2) pengawasan dan koordinasi kerja memiliki pengaruh signifikan secara simultan terhadap produktivitas kerja; (3) pengawasan kerja berpengaruh dominan secara signifikan terhadap produktivitas kerja karyawan.

\section{METODE PENELITIAN}

Penelitian tentang pengaruh pengawasan dan koordinasi kerja terhadap produktivitas kerja karyawan mempergunakan jenis penelitian eksplantori karena bertujuan melakukan pengujian terhadap hipotesis yang telah dirumuskan sebelumnya. Hipotesis tersebut disusun berdasarkan pengetahuan-pengetahuan yang telah ada atau berdasarkan penelitian sebelumnya dan pengalamanpengalaman ilmiah.

Penelitan terhadap populasi diharapkan dapat menggambarkan hasil yang sesungguhnya dari populasi. Data dikumpulkan dengan memberikan kuisioner pada operator dari karyawan salah satu perusahan multinasional di Sidoarjo.Sampel diambil berjumlah 200 orang. Teknik yang digunakan dalam penentuan sampel adalah random sampling, yaitu dengan mengambil sebagian anggota populasi sebagai responden yang terlibat dalam aktivitas produksi di pabrik tersebut. Sampel ditetapkan sebanyak 200 orang.

Untuk menjawab permasalahan yang telah dikemukakan pada pembahasan sebelumnya, maka penelitian ini menggunakan sumber data primer yaitu data yang dikumpulkan sendiri oleh peneliti dari objek penelitian. Data primer adalah data yang diperoleh dan dikumpulkan langsung dari lokasi penelitian melalui kuisioner yang diberikan kepada seluruh karyawan yang ditetapkan sebagai sampel. Kuesioner. Berupa seperangkat daftar pertanyaan yang diajukan secara tertulis kepada responden yang terpilih sebagai sampel. Pengukuran data di penelitian ini adalah kuesioner berdasarkan skala Likert.

Hasil data akan diuji validitas dan reliabilitas agar data yang diperoleh dapat dipercaya dengan menguji setiap butir pertanyaan yang ada pada kuesioner, apakah dapat mengungkapkan permasalahan dan apakah pertanyaan dapat dimengerti responden. Setelah itu uji asumsi klasik yang terdiri dari uji normalitas, uji multikolinearitas, uji heteroskedastisitas dan uji autokorelasi. Teknik regresi linier berganda digunakan untuk tahap selanjutnya melalui uji $\mathrm{F}$ dan uji t.

\section{HASIL PENELITIAN}

\section{Uji Reliabilitas dan Validitas}

Setelah melakukan analisis deskriptif terhadap data penelitian dan data responden, tahap selanjutnya adalah melakukan pengujian Validitas. Uji validitas digunakan untuk mengukur seberapa akurat daftar pertanyaan menangkap semua pernyataan dari para responden. Pada penelitian ini ditetapkan batas setiap item pertanyaan dinyatakan valid bila nilai corrected item total correlation lebih besar dari nilai 0,3 . Tabel 1 berikut menunjukkan bahwa untuk variabel pengawasan 
kerja (X.1) tidak ada item pertanyaan yang digugurkan. Kesimpulannya adalah setiap item pertanyaan pada variabel pengawasan kerja dapat dinyatakan valid.

Tabel 1

Uji Validitas Variabel Pengawasan kerja

\begin{tabular}{|lcr|lllllr|}
\hline \multicolumn{2}{|l}{ In d i k a t o r } & V a ri a b e l & N i l a i & V a l i d i t a s \\
\hline $\mathrm{X}$ & 1 &. & 1 & 0 &. & 8 & 1 & 1 \\
\hline $\mathrm{X}$ & 1 &. & 2 & 0 &. & 6 & 7 & 5 \\
\hline $\mathrm{X}$ & 1 &. & 3 & 0 &. & 6 & 8 & 5 \\
\hline $\mathrm{X}$ & 1 &. & 4 & 0 &. & 7 & 8 & 9 \\
\hline $\mathrm{X}$ & 1 &. & 5 & 0 &. & 8 & 0 & 1 \\
\hline $\mathrm{X}$ & 1 &. & 6 & 0 &. & 6 & 9 & 8 \\
\hline
\end{tabular}

Sumber: Output SPSS

Tabel 2 berikut menunjukkan bahwa untuk variabel koordinasi kerja (X.2) yang dinyatakan pada setiap item pernyataan, semua berada melebihi ambang batas 0,3 . Kesimpulannya adalah setiap item pertanyaan pada variabel koordinasi kerja dapat dinyatakan valid.

Tabel 2

Uji Validitas Variabel Koordinasi kerja

\begin{tabular}{|c|c|c|c|c|c|c|c|c|}
\hline \multicolumn{4}{|c|}{ Indikator Variabel } & \multicolumn{5}{|c|}{$\mathrm{Nila} \mathrm{i} \mathrm{V} \mathrm{a} \mathrm{lid} \mathrm{i} \mathrm{t} \mathrm{a} \mathrm{s}$} \\
\hline $\mathrm{X}$ & 2 & . & 1 & 0 & & 6 & 2 & 6 \\
\hline $\mathrm{X}$ & 2 & . & 2 & 0 & & 4 & 1 & 9 \\
\hline $\mathrm{X}$ & 2 & . & 3 & 0 & . & 6 & 2 & 7 \\
\hline$X$ & 2 & . & 4 & 0 & • & 7 & 5 & 6 \\
\hline $\mathrm{X}$ & 2 & . & 5 & 0 & & 6 & 0 & 1 \\
\hline $\mathrm{X}$ & 2 & . & 6 & 0 & & 7 & 2 & 1 \\
\hline
\end{tabular}

Sumber: Output SPSS

Tabel 3 berikut menunjukkan setiap item pernyataan, semua berada melebihi ambang batas 0,3 . Dengan demikian tidak ada item pertanyaan yang digugurkan. Kesimpulannya adalah setiap item pertanyaan pada variabel produktivitas kerja dapat dinyatakan valid.

Tabel 3

Uji Validitas Variabel Produktivitas kerja

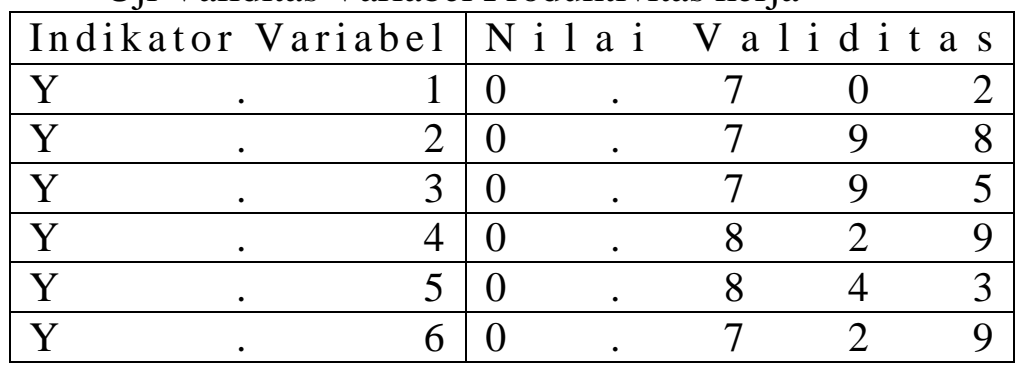

Sumber: Output SPSS

Selanjutnya adalah pengujian reliabilitas. Dalam pengujian reliabilitas ini digunakan untuk menunjukkan sejauh mana alat pengukur dapat dipercaya atau 
dapat diandalkan. Instrumen dikatakan reliabel apabila dipergunakan beberapa kali untuk mengukur obyek yang sama akan menghasilkan data yang sama. Untuk variabel bebas pertama yaitu pengawasan kerja (X.1) diperoleh nilai alpha sebesar 0,872 seperti ditunjukkan pada Tabel 4. Daftar pertanyaan tentang variabel pengawasan kerja dapat dipercaya atau dapat dihandalkan untuk menganalisis data selanjutnya.

\section{Tabel 4}

Uji Reliabilitas

\begin{tabular}{|c|c|c|c|c|}
\hline Indikator Variabel & $\mathrm{N}$ i 1 l a & & $\mathrm{p}$ & \\
\hline$X$ & 0 & 8 & 7 & 2 \\
\hline $\mathrm{X}$ & 0 & 8 & 4 & 3 \\
\hline $\mathrm{Y}$ & 0 & 7 & 6 & 4 \\
\hline
\end{tabular}

Sumber: Output SPSS

Untuk variabel bebas kedua yaitu koordinasi kerja (X.2) diperoleh nilai alpha sebesar 0,843 seperti ditunjukkan pada Tabel 4.Dengan demikian, item-item pertanyaan yang berhubungan dengan variabel koordinasi kerja (X.2) dinyatakan reliabel karena berada di atas 0.6.

Untuk variabel terikat yaitu produktivitas kerja (Y) diperoleh nilai alpha sebesar 0,764 seperti ditunjukkan pada Tabel 4. Daftar pertanyaan tentang variabel produktivitas kerja dapat dipercaya atau dapat dihandalkan untuk menganalisis data selanjutnya.

\section{Uji Asumsi Klasik}

Model regresi linier berganda akan lebih tepat digunakan dan menghasilkan perhitungan yang lebih akurat, bila beberapa asumsi klasik telah terpenuhi. Berikut ini adalah masing-masing uji yang dilakukan berdasarkan data yang terkumpul.

\section{Normalitas}

Uji normalitas bertujuan untuk menguji apakah dalam model regresi, variabel terikat dan variabel bebas keduanya memiliki distribusi normal atau tidak.

Gambar 2

Normal Probability Plot

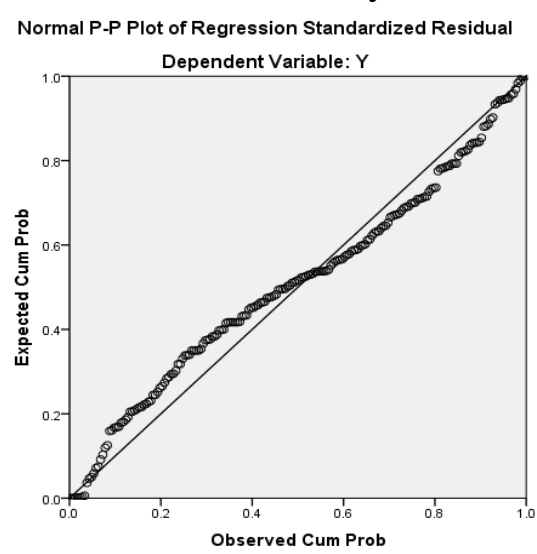

Sumber: output SPSS 
Jika distribusi data adalah normal, maka garis yang menggambarkan data sesungguhnya akan mengikuti garis diagnonalnya. Berdasarkan penjelasan tersebut maka dapat dibandingkan pada Gambar 2. Pada Gambar menunjukkan bahwa titik-titik mengikuti garis diagonal. Distribusi normal akan membentuk suatu garis lurus diagonal dan ploting data akan dibandingkan dengan garis normal. Dengan demikian dapat dikatakan distribusi data adalah normal.

\section{Heteroskedastisitas}

Uji heteroskedastisitas bertujuan menguji apakah dalam model regresi terjadi ketidaksamaan variance dari residual satu pengamatan ke pengamatan lain. Salah satu cara untuk mendeteksi ada tidaknya heteroskedastisitas pada suatu model persamaan regresi adalah dengan cara mengamati scatterplot pada dependent variable. Gambar menunjukkan bahwa titik-titik tersebar dan berada pada masingmasing bagian di sumbu Y. Dengan demikian dapat disimpulkan bahwa tidak terjadi heteroskedastisitas.

Gambar 3

Scatterplot Dependent Variable

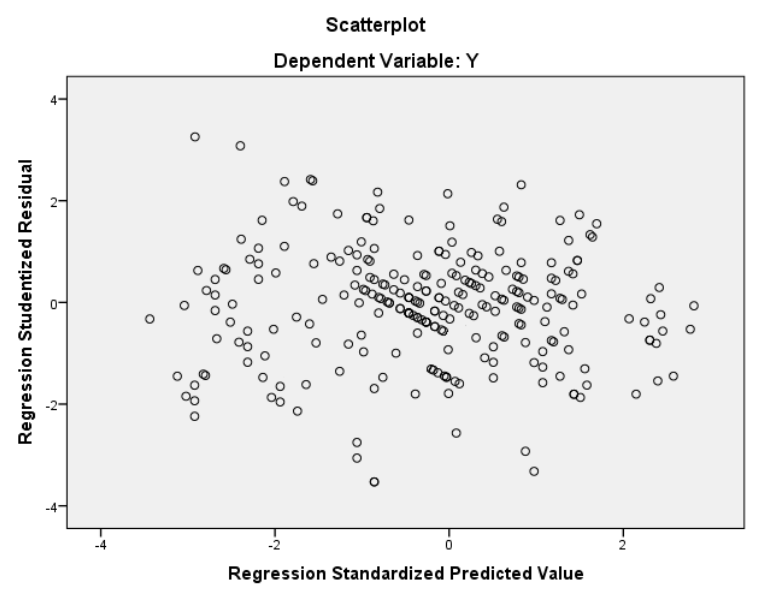

Sumber: output SPSS

\section{Multikolinieritas}

Uji Multikolinieritas dilakukan guna untuk mengetahui apakah faktor bebas tersebut tidak saling berkorelasi dan mendeteksi hubungan linier di antara faktor-faktor bebas dalam model regresi yang digunakan. Untuk mendeteksi multikolinieritas di dalam model regresi digunakan cara melihat nilai tolerance dan nilai VIF yang diperolehnya. Jika nilai tolerance yang diperoleh kurang dari 1 dan VIF antara 1 dan 2 maka dapat dikatakan bahwa persamaan suatu model penelitian tidak menunjukkan gejala multikolinieritas.

Tabel 5

Collinearity Statistics - Coefficients ${ }^{\mathrm{a}}$

\begin{tabular}{|c|c|c|c|c|c|c|c|c|c|c|c|c|}
\hline \multirow[b]{2}{*}{ Model } & & \multicolumn{11}{|c|}{ Collinearity $\mathrm{Statistics}$} \\
\hline & & $\mathrm{T}$ & C $\mathrm{o} \quad 1 \mathrm{e}$ & $\mathrm{r}$ & $\mathrm{a}$ & $\mathrm{n}$ & c & e & $\mathrm{V}$ & I & & $\mathrm{F}$ \\
\hline $\mathrm{X}$ & 1 & . & 6 & & 6 & & & 4 & 1 & 5 & 0 & 5 \\
\hline $\mathrm{X}$ & 2 & . & 6 & & 6 & & & 4 & 1 & 5 & 0 & 5 \\
\hline
\end{tabular}




\section{a. Dependent Variable: Y Sumber: Output SPSS}

Tabel 5 menunjukkan bahwa nilai tolerance yang diperoleh kurang dari 1 dan nilai VIF antara 1 dan 2. Dengan demikian dapat dinyatakan bahwa persamaan model penelitian ini tidak menunjukkan gejala multikolinieritas.

4. Autokorelasi

Uji asumsi klasik yang terakhir adalah uji autokorelasi. Tujuan dilakukannya pengujian autokorelasi adalah untuk menguji apakah dalam sebuah model regresi linier ada korelasi antara kesalahan pengganggu pada periode $t$ dengan kesalahan pada periode $\mathrm{t}-1$ (sebelumnya). Jika terjadi korelasi maka dinamakan ada problem autokorelasi. Untuk mendeteksi ada atau tidaknya korelasi ini dapat dilakukan dengan menggunakan uji Durbin Watson.

Tabel 6

Model Summary ${ }^{\mathrm{b}}$

\begin{tabular}{|lllll|llllll|}
\hline M & o & d & e & l & D u r b i n - W a t s o & a \\
\hline 1 & & & & & 1 &. & 7 & 0 & 7 & a \\
\hline
\end{tabular}

a. Predictors: (Constant), X.2, X.1

b. Dependent Variable: Y

Sumber: Output SPSS

Berdasarkan pada Tabel 6 maka dapat disimpulkan bahwa tidak ada masalah autokorelasi. Hal ini karena nilai Durbin Watson menunjukkan angka 1,707 yang berarti diantara nilai 2 dan -2 . Dengan demikian tidak ada masalah autokorelasi.

\section{Uji Hipotesis}

\section{Uji F}

Dengan Uji $F$ digunakan untuk membuktikan atau menguji pengaruh simultan dari variabel bebas terhadap variabel terikat. Adapun hasil perhitungan dengan menggunakan software SPSS seperti terlihat pada Tabel berikut ini.

Tabel 7

ANOVA $^{\mathrm{a}}$

\begin{tabular}{|c|c|c|c|c|c|}
\hline Model & $\begin{array}{c}\mathrm{S} \text { u } \mathrm{m} \text { o f } \\
\text { Squares }\end{array}$ & $\mathrm{df}$ & Mean Square & $\mathrm{F}$ & Sig. \\
\hline Regression & 1683.283 & 2 & 831.542 & 77.654 & $.001^{\mathrm{b}}$ \\
\hline $\mathrm{R}$ e $\mathrm{s}$ i d u a 1 & 2222.583 & 1997 & 10.740 & & \\
\hline To t a 1 & 3905.866 & 199 & & & \\
\hline
\end{tabular}

a. Dependent Variable: Y

b. Predictors: (Constant), X.2, X.1

Sumber: Output SPSS

Berdasarkan hasil dari uji $\mathrm{F}$ ini dilakukan dengan membandingkan nilai Probability sig. dengan batas yang ditentukan yaitu 0,05. Dari hasil 
perbandingan diperoleh nilai P Sig. pada Tabel diperoleh nilai 0,000 yang berarti berada di bawah batas 0,05 . Dengan demikian dapat dinyatakan bahwa pada taraf nyata $\alpha=0,05$, variabel bebas memiliki pengaruh secara simultan terhadap variabel terikat, atau dengan perkataan lain bahwa pada taraf nyata $5 \%$, hipotesis yang menyatakan variabel bebas berpengaruh signifikan secara simultan terhadap variabel terikat, diterima (terbukti).

\section{Uji t}

Uji t digunakan untuk membuktikan atau menguji pengaruh parsial dari variabel bebas terhadap variabel terikat. Adapun hasil perhitungan dengan menggunakan software SPSS seperti terlihat pada Tabel berikut ini.

Tabel 8

Coefficients $^{\mathrm{a}}$

\begin{tabular}{|c|c|c|c|c|c|c|c|c|}
\hline \multirow[b]{2}{*}{ Model } & \multicolumn{2}{|c|}{$\begin{array}{c}\text { Un s t a nd a rdi zed } \\
\text { Coefficients }\end{array}$} & \multicolumn{4}{|c|}{$\begin{array}{l}\text { S t a nd a rdi z e d } \\
\text { Coefficients }\end{array}$} & \multirow[b]{2}{*}{ l } & \multirow[b]{2}{*}{ Sig. } \\
\hline & B & Std. Error & B & $\mathrm{e}$ & $\mathrm{t}$ & $\mathrm{a}$ & & \\
\hline$(\operatorname{Constant})$ & 4.408 & 1.278 & & & & & 3.449 & .001 \\
\hline X. 1 & .503 & . 0660 & $\cdot$ & 4 & 6 & 8 & 7.181 & .000 \\
\hline X. 2 & 276 & . 0660 & . & 2 & 7 & 2 & 4.151 & .000 \\
\hline
\end{tabular}

a. Dependent Variable: Y

Sumber: Output SPSS

Berdasarkan hasil dari uji $\mathrm{t}$ ini dilakukan dengan membandingkan nilai Probability sig. setiap variabel bebas dengan batas yang ditentukan yaitu 0,05. Dari hasil perbandingan diperoleh nilai P Sig. pada Tabel diperoleh nilai 0,000 untuk variabel bebas pengawasan kerja (X.1), dan nilai 0,000 untuk variabel bebas koordinasi kerja (X.2) yang berarti berada di bawah batas 0,05 . Dengan demikian dapat dinyatakan bahwa pada taraf nyata $\alpha=0,05$, variabel bebas mempunyai pengaruh yang signifikan secara parsial terhadap variabel terikat yaitu produktivitas kerja, atau dengan perkataan lain bahwa pada taraf nyata 5\%, hipotesis yang menyatakan variabel bebas mempunyai pengaruh yang signifikan secara parsial terhadap variabel terikat (produktivitas kerja), diterima (terbukti).

\section{Persamaan Regresi Linier Berganda}

Berdasarkan Tabel sebelumnya diketahui pula persamaan regresi yang terbentuk seperti sebagai berikut. $\mathrm{Y}=4,408+0,503 \mathrm{X} .1+0,276 \mathrm{X} .2$

Dari persamaan ini terlihat variabel terikat $Y$ terus meningkat sebesar 4,408 seiring dengan makin terpenuhinya variabel bebas pengawasan kerja (X.1) sebesar 0,503 serta koordinasi kerja (X.2) sebesar 0,276.

Dari persamaan tersebut ditentukan variabel bebas yang berpengaruh dominan terhadap variabel terikat adalah pengawasan kerja (X.1) yang dilihat dari nilai Koefisien regresi tertinggi di antara varibel bebas, yaitu sebesar 0,503 atau lebih besar dari Koefisien regresi variabel koordinasi kerja (X.2) yang sebesar 0,276 . Variabel pengawasan kerja (X.1) adalah variabel bebas yang memiliki pengaruh dominan terhadap variabel terikat. Dengan demikian hipotesis di 
penelitian ini terbukti benar yang menyatakan bahwa pengawasan kerja (X.1) adalah variabel yang paling dominan berpengaruh terhadap variabel terikat.

\section{Koefisien Determinasi}

Koefisien determinasi berfungsi sebagai ukuran ketepatan atau kecocokan suatu jenis regresi terhadap kelompok data hasil observasi $\mathrm{R}^{2}$ mengukur proporsi atau prosentasi total variasi dalam $\mathrm{Y}$ yang dijelaskan oleh model regresi. Koefisien determinasi bergerak dari 0 sampai 1, semakin mendekati 1 semakin baik.

Tabel 9

Model Summary

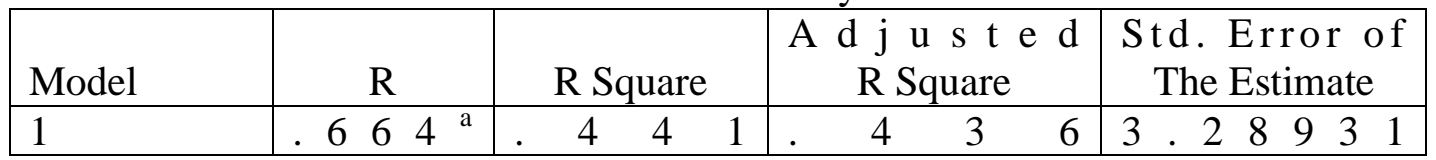

a. Predictors: (Constant), X.2, X.1

Sumber:Output SPSS

Berdasarkan pada hasil penghitungan di atas, koefisien $\mathrm{R}$ square sebesar 0,441 menunjukkan adanya pengaruh yang cukup kuat antara variabel bebas dengan variabel tidak bebas (terikat). Koefisien determinan sebesar 0,441 menunjukkan bahwa model regresi berganda ini yang variabel bebasnya terdiri dari pengawasan kerja (X.1) dan koordinasi kerja (X.2) telah memberikan kontribusi sebesar 44,1 \% terhadap pembentukan variabel terikat, yaitu produktivitas kerja. Sedangkan sisanya sebesar 55,9\% ditentukan oleh faktor-faktor lain.

\section{PEMBAHASAN}

Temuan penelitian mengarah kepada pembuktian hipotesis penelitian. Berikut ini beberapa pembahasan mengenai hal tersebut. Hipotesis pertama menyebutkan bahwa pengawasan kerja dan koordinasi kerja berpengaruh signifikan secara parsial terhadap produktivitas kerja karyawan. Nilai P. Sig pada tabel coeffcients menunjukkan angka sebesar 0,000 (X.1), 0,000 (X.2) atau lebih kecil dari 0,05 untuk masing-masing variabel bebas. Dengan demikian dapat dinyatakan bahwa variabel-variabel bebas yang terdiri dari pengawasan kerja dan koordinasi kerja berpengaruh signifikan secara parsial terhadap produktivitas kerja karyawan. Berdasarkan hasil analisis data dapat dinyatakan bahwa hipotesis pertama tersebut terbukti benar.

Hipotesis kedua menyebutkan bahwa pengawasan kerja dan koordinasi kerja berpengaruh signifikan secara simultan terhadap produktivitas kerja karyawan. Nilai P. Sig yang tertera pada tabel anova menunjukkan angka sebesar 0,000 atau lebih kecil dari 0,05. Dengan demikian dapat dinyatakan bahwa variabel-variabel bebas yaitu pengawasan kerja dan koordinasi kerja berpengaruh signifikan secara simultan terhadap produktivitas kerja karyawan.Berdasarkan hasil analisis data dapat dinyatakan bahwa hipotesis kedua tersebut terbukti benar.

Hipotesis ketiga menyebutkan bahwa koordinasi kerja berpengaruh dominan secara signifikan terhadap produktivitas kerja karyawan. Di antara nilai Koefisien 
regresi yang ditemukan, terlihat pada tabel coeffecients nilai Koefisien variabel bebas pengawasan kerja sebesar 0.503 yang berarti lebih besar dibandingkan nilai koefisien variabel bebas koordinasi kerja. Dengan demikian variabel bebas pengawasan kerja memiliki pengaruh yang paling dominan dibandingkan variabel bebas koordinasi kerja terhadap variabel terikat yaitu produktivitas kerja karyawan. Hal ini menunjukkan bahwa hipotesis ketiga di penelitian ini terbukti benar.

Adanya pengawasan dan koordinasi kerja meningkatkan peran dan partisipasi karyawan terhadap pekerjaannya. DeCenzo dan Robbins (2005) menemukan keterlibatan dan partisipasi karyawan, memastikan bahwa karyawan benar-benar cocok dalam pekerjaan mereka dan sepenuhnya menyadari tingkat kewenangan mereka, dan membiasakan mereka dengan apa yang diharapkan adalah semua faktor yang menghilangkan stres, konflik, dan ambiguitas di organisasi. Adanya tekanan terhadap pekerja dari tindakan pengawasan bukan menjadi penghambat seutuhnya. Tekanan justru direkomendasikan untuk organisasi yang sehat dan tanpa itu, karyawan kekurangan energi untuk bekerja lebih maksimal (DeCenzo dan Robbins, 2005). Meski demikian harus ada keseimbangan antara upaya peningkatan produktivitas dan sisi humanisnya. Keseimbangan yang dimaksud adalah keseimbangan peningkatan produktivitas dan efisiensi dibandingkan dehumanisasi tempat kerja (Thompson dan Cats-Baril, 2003). Pengawasan dan koordinasi kerja mengedepankan hubungan interpersonal antara kedua belah pihak yang berkepentingan dan hal itu diharapkan semakin meningkatkan kualitas hubungan kerja dan menjaga kondusivitas lingkungan dan iklim kerja di organisasi.

\section{PENUTUP}

\section{Kesimpulan}

Penelitian ini bertujuan untuk mengetahui pengaruh pengawasan dan koordinasi kerja berpengaruh signifikan secara simultan dan secara parsial terhadap produktivitas kerja. Dari temuan penelitian yang telah diuraikan pada bagian sebelumnya, maka penulis akan menetapkan beberapa hal terkait dengan kesimpulan di penelitian ini. Kesimpulan yang dapat ditetapkan adalah (1) pengawasan dan koordinasi kerja berpengaruh signifikan secara parsial terhadap produktivitas kerja; (2) pengawasan dan koordinasi kerja berpengaruh signifikan secara simultan terhadap produktivitas kerja; (3) pengawasan kerja terbukti berpengaruh dominan secara signifikan terhadap produktivitas kerja.

\section{Saran}

Berdasarkan hasil pembahasan dan kesimpulan yang telah diuraikan, maka selanjutnya penulis mengajukan saran yang ditujukan kepada karyawan bahwa dengan adanya pengawasan dan koordinasi yang dilakukan oleh pihak perusahaan diharapkan karyawan dapat termotivasi terhadap produktivitas kerja, sehingga dapat meningkatkan kemajuan perusahaan tersebut. Bagi perusahaan, kegiatan pengawasan dan koordinasi kerja perlu terus dikembangkan secara metode agar pendekatan yang lebih humanis dapat terwujud dan mendukung efektivitas pelaksanaannya. Untuk penelitian selanjutnya dapat meneliti pada faktor-faktor penyebab peningkatan produktivitas kerja seperti motivasi, disiplin, lingkungan 
dan iklim kerja dengan jumlah sampel yang jauh lebih banyak, sehingga diperoleh pengetahuan yang lebih baik lagi dalam melihat penyebab peningkatan pada produktivitas kerja. Selain itu studi lebih lanjut dapat mengeksplorasi gaya, sifat, dan perilaku kepemimpinan yang paling efektif yang diperlukan untuk memantau produktivitas kerja dengan menggunakan teknologi dalam organisasi. Ini juga akan berguna jika kita bisa menyadari sejauh mana pihak perusahaan harus mendalami lebih jauh mengenai pengamatan perilaku karyawan di organisasi.

\section{DAFTAR PUSTAKA}

Armstrong, Michael. 2010. Seri Pedoman Manajemen. Manajemen Sumber Daya Manusia. Alih bahasa oleh Sofyan Cikmat dan haryanto Elex Media Komputindo. Jakarta.

Bacal, Robert. 2002. Performance Management. PT Gramedia Pustaka Utama. Jakarta.

Creswell, John. W. 2014. Penelitian Kualitatif \& Desain Riset. Pustaka Pelajar, Yogyakarta

Darmawan, Didit. 2013. Prinsip-Prinsip Perilaku Organisasi. Pena Semesta, Surabaya

DeCenzo, D. A., \& Robbins, S. P. 2005. Fundamentals of Human Resource Management (8th ed.). New Delhi, India: John Wiley.

Gunawan, Aditya. 2017. Manajemen Sumber Daya Manusia. MetroInsight. Jakarta.

Handoko,T Hani. 2013.Manajemen. BPFE UGM. Yogyakarta.

Handayaningrat, Soewarno. 2002. Pengantar Studi Ilmu Administrasi dan Manajemen. CV. Haji Masagung, Jakarta

Kadarisman. 2013. Manajemen Pengembangan Sumber daya Manusia. Rajagrafindo Persada, Jakarta.

Robbins, Stephen P dan Timothy A Judge. 2014. Perilaku Organisasi. Jakarta: Salemba Empat.

Siagian,Sondang P. 2008. Manajemen Sumber Daya Manusia.PT. Bumi Aksara, Jakarta

Syafrudin, Ateng. 2003. Pengaturan Koordinasi Pemerintahan di Daerah. Bumi Aksara, Bandung

Thompson, R. L., \& Cats-Baril, W. L. 2003. Information technology and management (2nd ed.). Boston, MA: McGraw-Hill/ Irwin 